\title{
Unravelling ambivalence: A field-theoretical approach to moralised markets
}

\section{Lisa Suckert}

Max Planck Institute for the Study of Societies, Germany

\begin{abstract}
Moralised markets are often referred to as ethical consumption markets. They are supposed to relieve a source of major distress in capitalist societies: the conflict between morality and economy. But under what conditions do these markets grow, and when do they stagnate? Deviating from the dominant focus on external constraints, this article emphasises the intrinsic ambivalence of moralised markets. Being caught between moral and economic exigencies becomes an obstacle for market growth. The article addresses 'unravelling ambivalence' on two levels. First, a field-theoretical framework is used to unravel the concept of ambivalence. Inspired by Pierre Bourdieu, the article proposes introducing ambivalence as an analytical category in economic sociology. Second, a historic study based on correspondence analysis depicts the development of the German organic milk market. What distinguishes growth from stagnation is the degree of ambivalence within this market. Only if opposition is mitigated and ambivalence unravels into a more pluralistic field structure does the transition from niche to mass market become viable.
\end{abstract}

\section{Keywords}

Ambivalence, Bourdieu, conventions, economic sociology, field theory, markets, morality, multiple institutional logics, sustainability

\section{Introduction}

Moralised markets are booming. Ranging from fair trade coffee or Islamic finance to green housing - today's markets are increasingly infused with moral commitments. Milton Friedman's claim that 'the social responsibility of business is to increase its profits' (1970) therefore seems, at least at first glance, quite obsolete. Yet, the novelty is not

\section{Corresponding author:}

Lisa Suckert, Max Planck Institute for the Study of Societies, Paulstrasse 3, Köln 50676, Germany.

Email: suckert@mpifg.de 
the mere presence of moral values in market domains. Markets have always been influenced by the moral expectations of the cultures in which they are embedded. What distinguishes moralised markets from 'ordinary' markets is their explicit morality. Here, morality is not one latent aspect among others, but a key principle of market interaction. Market actors explicitly justify their production and distribution decisions with reference to moral principles. In this respect, the 'moralization of markets' (Stehr et al., 2006) is, indeed, a recent phenomenon.

Academia has both monitored and promoted the emergence of moralised markets. The field of sustainable business studies has particularly focused the transition from niche to mass market and identified some external constraints that need to be overcome: e.g. consumers' (un)willingness to pay, inadequate channels of distribution, opposition from powerful external competitors or imperfect regulation (Gibbs, 2009; Hockerts and Wüstenhagen, 2010; Schaltegger, 2010; Villiger et al., 2000). The proposed remedy is to draw on appropriate management practices and the resulting economies of scope. According to sustainable business studies, moralised markets, like other markets, need to reach a critical mass, which will then generate further growth.

What has, however, received less attention as a constraint for growth, is the characteristic concern of these markets with morality. In many cultures, moral concerns not only differ from economic rationality but, more often than not, morality is explicitly defined as opposing economic rationality. ${ }^{1}$ From a sociological perspective, this inherent ambivalence of moralised markets is crucial. Moralised markets are simultaneously exposed to opposing sets of values: products, participants and practices are not only judged according to a cost-benefit calculus, but have to meet normative expectations concerning, for example, the environment, working conditions, human rights and gender mainstreaming. The contradiction between economic and moral requirements gives rise to potential tensions and conflicts. Ambivalence can thus become an intrinsic constraint to the evolution and persistence of moralised markets.

This socio-economic article proposes a field-theoretical approach to the growth of moralised markets. It argues that the inherent ambivalence originating from the opposition between morality and economy requires closer scrutiny than it has received in sustainable business studies. The dynamics of moralised markets, i.e. their capacity to grow or, conversely, their inability to thrive, need to be explored against the backdrop of ambivalence as a basic pattern of market structure. A historic study of the German organic milk market substantiates this field-theoretical argument. Comparing phases of growth and stagnation elucidates how excessive structural ambivalence hampers the capacity to grow. To overcome such constraints, markets need to cope with the opposition between morality and economy and - at least partially - unravel the ambivalence they face.

Similar to this perspective, (sociological) organisation studies have acknowledged conflicting logics within moralised markets and explored how organisations cope with them. Referring to concepts such as hybrid organisation (Mair et al., 2015; Murray, 2010; Pache and Santos, 2013), ecopreneur or sustainability entrepreneur (Child, 2012; Phillips, 2013; Suckert, 2014), the ability to integrate conflicting logics is depicted as a competitive advantage. 
Yet, while these studies give valuable insights into actors' coping strategies and their favourable or unfavourable effects, the findings of this study demonstrate that ambivalence is more than just a feature of economic decision-making. It is a structuring principle of moralised markets and their evolution. Drawing on Bourdieusian concepts, this perspective considers the historical and structural context which embeds, i.e. enables and constrains, actors' coping strategies. It can therefore complement approaches in organisation studies and expand our knowledge on moralised markets.

The first two sections of the article depict the field-theoretical framework and its contribution to the ongoing debate. They show why economic sociology should examine opposing logics more comprehensively and to this end propose Bourdieu's idea of opposing economies of the social. The historic case of the German organic milk market is then introduced, depicting phases of both stagnation and growth. Correspondence analysis reveals how the opposition between economy and morality persistently structures the market. However, this structure is gradually transformed from a dichotomous bipolar field to a multidimensional one. Ambivalence does not disappear but progressively unravels - facilitating further market growth. The conclusion discusses the implications and limitations of these findings.

\section{Economic sociology and the implicit omnipresence of ambivalence}

In his ASA presidential address, Neil Smelser (1998) promoted ambivalence as a 'fundamental idea ... that is essential for understanding individual behavior, social institutions, and the human condition generally' (p. 1). He considered ambivalence an antidote to the predominance of simplistic rational choice approaches denying all non-rational forces. In line with Smelser, I argue that ambivalence should be considered a key concept - if not in the social sciences, then at least in economic sociology.

The concept of ambivalence originates from Eugen Bleuler (1914). The psychologist used it for strongly opposing but simultaneous affects, wants or valuations regarding the same object. Individuals thus experience contrasting impulses (love/hate, attraction/ repulsion) towards an object, symbol, person or practice. Emanating from psychology, ambivalence characterises more than individuals' feelings; it also encompasses the social situations which, laden with normative expectations, cause these feelings (Merton, 1976). Ambivalence thus refers to social instances where two opposing logics are present and both (Lat. ambos) are valid (Lat. valere). These opposing sets of values direct actors towards opposing goals, simultaneously provoking both attraction and repulsion. In ambivalent situations actors cannot decide which values matter: 'We want both sides at once but cannot fully satisfy either side' (Smelser, 1998: 13).

The existence of divergent and often opposing sets of values is implicitly omnipresent in new economic sociology (NES). It is already inherent to Mark Granovetter's paradigm of embeddedness. Accordingly, economic action cannot be reduced to rational profit maximisation of atomised actors. Instead, 'the economic' is constantly irritated by divergent sets of value: 'The pursuit of economic goals is typically accompanied by that of such noneconomic ones as sociability, approval, status, and power' (Granovetter, 1992: 
25). These 'noneconomic' logics are not only mitigated through networks but are genuinely social: atomistic individuals cannot long to achieve sociability, approval, status, power - or moral integrity. Being embedded in social relations, the economic realm is full of 'trade-offs among economic and noneconomic motives' (1992: 26). Ever since, NES has been attempting to identify these 'noneconomic motives' in the (supposedly) economic realm. Many of NES's seminal works either show that due to noneconomic factors, economic outcomes are not what economics would expect (e.g. Fligstein, 1990; Powell and DiMaggio, 1983); or they describe how the noneconomic is a precondition for the economic (e.g. Beckert, 2009; Zelizer, 1983). Despite its dedifferentiational impetus, major strands of NES subtly build on the dichotomy between the economic and the noneconomic (cf. Sparsam, 2015). Ambivalence, i.e. the simultaneous validity of two opposing sets of values, is therefore implicitly omnipresent.

Surprisingly, NES has not yet developed a comprehensive approach to ambivalence. Inspired by the Bourdieusian idea of 'economies of the social', the next section bridges this gap with a field-theoretical framework. However, we first explore two strands loosely related to NES (Jagd, 2007) which offer similar potential for the analysis of ambivalence. The neo-institutionalist concept of competing institutional logics (IL) (Friedland and Alford, 1991; Thornton and Ocasio, 1999) assumes that in complex institutional fields, actors are exposed to multiple and often conflicting institutional exigencies. Originally linked to the study of organisational change and questions of legitimacy, scholars have elucidated organisational coping strategies for meeting multiple expectations (e.g. Bode, 2015; Reay and Hinings, 2009). Similarly, économie des conventions (EC) (Boltanski and Thévenot, 2006; Diaz-Bone and Salais, 2012) emphasises the plurality of legitimating conventions. Intended as a pragmatist antidote to French structuralism, the approach focuses on situations as primary units of analysis. It analyses how reflexive actors temporarily mitigate conflicts by crafting compromises between conventions - and how conflict arises again (Thévenot, 2001). In both approaches, the social world is not governed by one particular logic or convention, such as economic rationalism, but by multiple principles and their dynamic interaction (Diaz-Bone, 2014). This genuine pluralism is required to make ambivalence accessible in the first place. Indeed, scholars from both approaches have also addressed the specific conflicts of moralised markets (Hahn et al., 2016; Knoll, 2012; Mair et al., 2015; Suckert, 2014).

Ever since Bleuler, ambivalence has referred to one particular configuration of principles: outright opposition. In an ambivalent situation, one principle is defined by not being the other, e.g. the economic and the noneconomic. With some exceptions (e.g. Bode, 2015), opposing (i.e. mutually exclusive) sets of values have not been on the agenda because neither IL nor EC specify the configuration(s) of their logics or conventions: these may be conflicting, competing, overlapping, compromising or merely differing. Though these frameworks can indeed sensitise NES to the plurality and interaction of governing principles, they do not provide frameworks to enable reflection on the causes, consequences and dynamics of opposing principles, i.e. on ambivalence.

Moreover, in both EC and IL, structure is (intentionally) of peripheral concern. While the former perceives conventions as being tied to situational arrangements of objects and explicitly neglects their anchorage in social structure, the latter conceives structure as 
cultural, cognitive patterns and emphasises the importance of constituencies' interests. In both strands, coping with multiple principles is accomplished by the agency of social actors. Ambivalence and actors' capacity to cope with it is thus considered neither to be enshrined in social structure nor related to its historic emergence and development.

The field-theoretical approach proposed in the next section deviates from this perspective. While it emphasises the coexistence of multiple sets of values, i.e. different economies of the social, it also points to the opposition between such principles. The ambivalence implicitly referred to by NES - economic vs noneconomic motives - can thus be grasped conceptually. Moreover, ambivalence is related to a comprehensive field-theoretical perspective. It is, therefore, not only perceived as an individual challenge but as a structuring principle.

\section{Field theory and economies of the social: Discerning ambivalence in market fields}

The essence of the Bourdieusian perspective on markets is seeing them as fields (e.g. Bourdieu, 1997; Bourdieu and Christin, 1990). Bourdieu's notion of 'market fields' has attracted considerable enthusiasm within economic sociology: while Neil Fligstein built his approach to markets on it (Fligstein, 2002; Fligstein and McAdam, 2011), Jens Beckert (2010) proposes this concept to overcome unnecessary segregation of market sociology. Richard Swedberg even considers fields to be 'the only existing theoretical alternative in economic sociology to the model of embeddedness' (2009: 47; 2011). Thus, an approach to ambivalence that connects to ongoing field-theoretical debates within economic sociology seems appealing.

But what does it mean to define markets as fields? A market field is held together neither by mutual interactions (networks) nor by impermeable borders (formal institutions). Like a magnetic field, it is bound by some intangible force from within: market fields are bound by the shared belief of mutual competition. Consequently, I consider market fields as sets of competing actors oriented towards one another and sharing assumptions about legitimate market practices. In modern fixed-role, mass-production markets competition usually concerns trading opportunities. Therefore, the notion of market field, though conceptually broader, primarily refers to producers or retailers vying for predominance.

What distinguishes Bourdieusian from other field theories (e.g. Fligstein and McAdam's prominent approach) is the analytical triad of field, habitus and capital. I propose complementing this triad with another Bourdieusian concept: the economies of the social. This concept is ideally suited for analysing ambivalence in market fields and complementing NES, IL and EC. Starting with his Algerian studies (1972, 1996a), opposing and interacting value systems were of major interest to Bourdieu. His overall goal was to develop a general economic theory (Bourdieu, 2002). Therefore, concepts such as field-specific rules, habitus or plurality and transformability of capitals are suitable for different types of economies.

Following Bourdieu (1994), a basic distinction is to be made between economic economies and symbolic, i.e. noneconomic, economies. In the economic economy (Bourdieu, 1997), self-interest and profit maximisation are legitimate principles. The main type of 
capital is financial capital. It is used to rate other resources by formulating prices. Moreover, struggles occur openly. Competition is an obvious virtue. These characteristics are integrated into a specific economic habitus resembling the dispositions of homo oeconomicus described by economics. It enables actors to judge according to an explicit cost-benefit calculus. In contrast, Bourdieu describes the symbolic economy by one basic characteristic: rejection of the economic economy. This economy does 'not function according to the law of interest seen as the search for the maximization of (monetary) profit' (1998: 93). On the contrary, the dominant principle is to subordinate self-interest (at least apparently) to higher, noneconomic values. While there is an economic logic capital is transformed and accumulated, most of the time with the incumbents - this logic remains implicit. It is actively disguised. Incorporated into the symbolic habitus, it is hardly accessible to reflexivity. The characteristic 'symbolic' capital can be accumulated through any resource or behaviour that evokes the appreciation of others. However, it is specifically acquired through moral behaviour perceived as selfless (Bourdieu, 1994). For the organic markets depicted below, symbolic capital is obtained by (apparently) engaging in the moral endeavour of environmental protection. Ecological integrity is thus a crucial capital that I will refer to as 'eco-symbolic' capital.

The distinction between economic and symbolic economies is one of 'ideal types'. It elucidates how the principles at work differ and, even more importantly, oppose one another. Yet, in line with EC and IL approaches, Bourdieu was aware that the empirical reality is more complex. Empirical fields, e.g. market fields, are always driven by a more or less pronounced mixture of economies. Consequently, fields are often portrayed as dualistic structures, stretched between an autonomous pole of the symbolic logic ('the sacred') and a heteronomous pole of the economic logic ('the profane') (Bourdieu, 1996b). Therefore, field struggles cannot be reduced to the survival of incumbents and challengers, but also involve conflicts between opposing sets of values.

These conflicts between 'the sacred' and 'the profane' can also illuminate processes of field transformation. Though Bourdieu's perspective is focused on reproduction and was indeed often reproached for neglecting dynamics, he repeatedly suggested his concepts to study change. From a field perspective, real change is tied to a transformation of the underlying capital structure, i.e. what is acknowledged as valuable within a specific field. The struggles emerging between opposing economies of the social are therefore driving forces behind such transformations. At times, Bourdieu hints at the role of 'dual beings' who 'accumulate ... the advantages of two antithetical logics' (Bourdieu, 1996b: $8)$, i.e. actors with access to both economies. Their dual habitus allows them to mitigate and alter the underlying opposition. While Bourdieu remains vague about his 'dual beings', both EC and IL offer more developed theories: EC spells out how reflexive actors establish forms, objects or intermediaries to strengthen compromises between divergent conventions; IL refers to institutional entrepreneurs or hybrid actors who shape and alter conflicts between logics (Mair et al., 2015; Murray, 2010). But again, these theories provide significant insights on the micro level - which is not the primary focus of this article - while field theory stresses the structural embeddedness of individual acts. Internal struggles and efforts to reconcile economies of the social, as EC and IL describe them, only foster profound structural transformations if they are supported by broader external influences or exogenous shocks (cf. Fligstein and McAdam, 2012: 99). In order 
to transform the field structure, its underlying capitals and oppositions, actors need to draw on broader social dynamics external to the field (e.g. changing values) and link them to the initial struggles and valid economies of the social.

How can the idea of economic and symbolic economies help us to understand ambivalence in markets? Much of the bustling activity on markets can indeed be understood as economic economy. Bourdieu's concept of symbolic economies then unmasks other, noneconomic, logics that frame the way markets work. Even if they oppose economic rationality, field theory allows describing these logics with the same general concepts. It depicts how the orientation towards opposing sets of values results in different forms of capital, conflicting habitus or irreconcilable ideas about legitimate practices. Ambivalence thus becomes tangible.

Consequently, the market sociological potential of Bourdieu's theory is greatest for markets with pronounced ambivalence, i.e. where noneconomic factors are extensively valid (Clercq and Voronov, 2009; Rosenkranz, 2016; Varriale, 2015; Witman et al., 2011). Considering divergent 'economies of the social' appears similar to EC or IL approaches. Yet, field theory goes beyond concluding that markets are governed by multiple logics/conventions and revealing individual coping strategies. It permits a detailed investigation of the nature of their opposition and anchorage in the overall market structure. The suggested approach can thus sensitise to ambivalence while linking in with more structural concepts already prominent within NES. Moreover, acknowledging the opposition of logics and the emerging structural conflicts can help to understand how markets transform and evolve.

The explanatory power of this approach guides this study of moralised markets. Striving for economic growth and protecting moral integrity, the two paradoxical exigencies of moralised markets are the goals of two opposing economies - one that sets out to maximise financial profit, and one that seeks to generate appreciation for doing good. In these market fields, economic and symbolic logics apply at one and the same time. My study on the German organic milk market exemplifies a field analysis focused on ambivalence. It shows how this more structural perspective is crucial to understanding the historic evolution of a moralised market from niche to mass market.

\section{The German market for organic dairy products: Stagnation and growth}

Field theory emphasises historicity. To understand the current structure, its underlying principles and oppositions, we must take the emergence and development of a field into account. Consequently, the German organic dairy market is introduced by depicting its historic evolution. My account emanates from an in-depth historical analysis of contemporary documents, including newspapers, reports, industry journals, government bulletins and secondary literature (Suckert, 2015: 169). Distinguishing phases of stagnation and growth sets the stage for the subsequent comparative field analysis.

Germany is one of the largest markets for organic food. The majority of its turnover is generated by organic dairy products: 240 million euros in 2012. However, the beginnings of the German organic milk market were more modest. During the first decades of the 20th century, individual dairy farmers geared their production towards environmental 


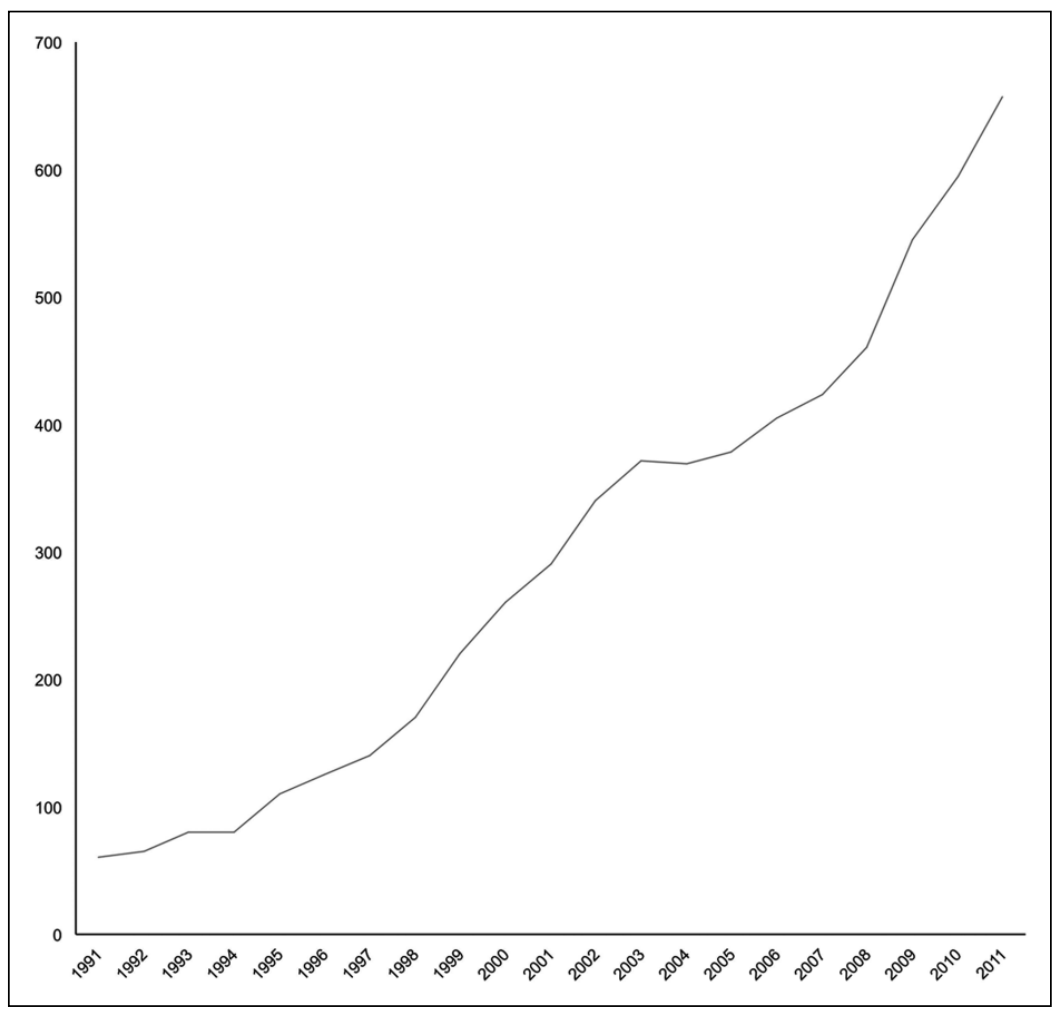

Figure I. The evolution of the market: Organic milk delivered to dairies (in million $\mathrm{kg}$ ). Adapted from data from Ökomarkt Jahrbuch, 2007: 204; BÖLW ZahlenDatenFakten, 2012: 9.

concerns. By the 1970s and early 1980s, small alternative channels of distribution, e.g. agricultural cooperatives, emerged. A market with its own institutions and value chain evolved. Figure 1 illustrates the subsequent expansion (1991-2011) by the amount of organic milk delivered to dairies. Other indicators would similarly substantiate the impressive market growth observed for more than two decades.

In the 1980s, very little organically produced milk was marketed as 'organic'. There were only six dairies explicitly processing organic milk in 1983. Consequently, farmers either sold their milk directly to consumers or delivered it to conventional dairies which then sold it as 'conventional' milk. However, organic dairies and distributors multiplied by the end of the 1980s, facilitating enormous growth from 1995 on (see Figure 1). Demand increased, prices increased and new players, including conventional supermarkets and big dairy trusts, were drawn to the market.

The turn of the millennium was supposed to further stimulate this economic upturn. In 2001, the federal eco-label 'Bio-Siegel' was introduced for milk products and expected to attract new consumers. Moreover, the first discount stores entered the organic market, which increased potential distribution. But, despite these two events and the high hopes accompanying them, expansion came to an end in 2001 and was followed by stagnation. 
Surprisingly, demand for organic milk declined, destructive competition set in and prices plummeted. Some smaller organic dairies were forced into bankruptcy or taken over by larger competitors. Participants wondered whether the market had already reached its supposed 'limits of growth'. Consequently, some conventional dairy trusts left the organic market again and numerous organic farmers reconverted.

However, since the middle of the decade, the market has recovered, displaying unprecedented growth. Producer and consumer prices rose and, from 2006, even uncoupled from conventional milk prices - finally indicating the independence of organic and conventional markets. Since then, various smaller organic dairies have been (re-)established and some conventional competitors have entered the market. Today there are approximately 60 dairies processing and marketing organic milk. In addition, several international dairy companies have become active in the German market.

The organic milk delivered to dairies, depicted in Figure 1, can serve as an important (if slightly time delayed) indicator for the above development. But how can the kinks in the graph, i.e. the unexpected phase of stagnation (2001-2005) and the subsequent accelerated upturn (2005-present day), be explained? Market participants and observers (e.g. ZMP, 2002) have suggested various explanations. The downturn is often considered to be an effect of overproduction, loss of consumer trust, destructive competition or simply 'growing pains' due to the transition from niche to mass market. Recovery is then attributed to consumers' increasing environmental awareness and a simultaneous 'de-ideologisation' of the sector. In line with sustainable business studies, these factors constitute valid elements of an explanation. However, addressing this question from a field-theoretical perspective provides new insights. The analysis below thus compares the market's overall field structure in phases of stagnation and growth. It elucidates how ambivalence feeds into these changing market dynamics. First I present my data and method, and then I follow up with my findings.

\section{Depicting markets as fields: Data and method}

Organic dairies are the core of the examined market field. While the market for organic dairy products incorporates farmers, consumers and retailers, these participants are active in a variety of markets. For organic dairies, however, this market is the bedrock of their existence. In Bourdieusian terms, only they cherish the 'illusio' of the market they are bound to. Today, approximately 60 dairies process organic milk. I identified nine of these as the market field in a narrow sense. As mentioned, market fields are bound by the shared belief of mutual competition. In interviews, representatives of these nine dairies indicated each other as competitors. ${ }^{2}$ Moreover, they were considered 'relevant competitors' in public debates about organic milk. ${ }^{3}$ Therefore, my analysis explores them as a market field along different points in time.

Accounting for markets as fields implies a focus on objective relations, i.e. relative similarities and differences between participants. A field-theoretical approach spells out which fundamental oppositions govern the field and how these oppositions translate into divergent resources of power. The Bourdieusian notion of capital is crucial in this endeavour. Capital refers to any resource, capability or quality that grants power to its possessor. However, what is considered to be capital is relative to the field. For example, a $\mathrm{PhD}$ in management studies may be either an advantage or a burden in the respective 
fields of 'consultancy' and 'punk rock'. Emanating from Bourdieu's ideal types of social, symbolic, economic and cultural capital, valid forms of capital have to be developed empirically. But what criteria can we use to distinguish organic dairies? What are the relevant forms of capital within this market field?

Inspired by Bourdieu's types of capital but based on an in-depth historical analysis of the industry, I developed a set of indicators. These comprise 13 key indicators identifying potential resources of power within the market field (see Table 1). Sixteen additional variables further illustrate these resources. The indicators were, as far as possible, collected for all nine dairies from 1985 to 2011.4

Based on this dataset I conducted a multiple correspondence analysis (MCA) for phases of stagnation and growth. MCA is profoundly interlocked with field theory (Greenacre and Blasius, 2006). ${ }^{5}$ Based on cases and categorical variables - here: dairies and their power resources - MCA calculates a multidimensional sphere or, in Bourdieuisan semantics, a field. Within this field, the location of variables and cases depicts their relative positions, i.e. proximities and differences. The graphical representation of MCA is central to this explorative tool. Correspondence maps usually display the first two dimensions of the analysis and locate variables (or cases) accordingly. The visualisation of underlying oppositions makes MCA an excellent tool for discerning ambivalence. For the organic dairy market, MCA allows identifying the potential resources that make a difference and the oppositions according to which they are distributed.

Field theory emphasises a historic, evolutionary understanding of field structure. I argue that MCA is also suitable for mapping changing market fields. Using data for different time points, MCA can display the respective contemporary structures of the market. Diachronic comparison then depicts the evolution of the market field and its inherent ambivalence. $^{6}$

\section{Mapping the evolution of ambivalence: The changing structure of the market field}

Ambivalence is the simultaneous validity of two opposing sets of values, e.g. economic and explicitly noneconomic values. I argue that the field-theoretical perspective of economies of the social provides credible concepts to help discern ambivalence. Moreover, MCA serves as associated methodological tool for exploring ambivalence empirically. But how does ambivalence help us to understand the structure and dynamics of empirical moralised markets? The findings show that (1) ambivalence is a major pattern structuring the moralised market examined and that (2) the transition from a stagnating niche market to a growing mass market is accompanied and facilitated by structural transformations which mitigate oppositions and thus 'unravel' ambivalence.

Figure 2 shows the correspondence map for 2001. It presents the structure of the German organic dairy market on the cusp of stagnation. From this point, the market experienced several years of economic downturn. The essential detail of this graph is not the localisation of the variables but the explained variance. The first dimension accounts for more than $70 \%$ of total variance, while the second dimension explains only $14 \%$ and the third dimension only $9 \%{ }^{7}$ This field is almost one-dimensional. 
Table I. Potential resources of power within the market field.

Indicator Description
Codes

Turnover (million €/year)

Turnover_S; Turnover_M; Turnover_L

Volume of processed organic milk (million kg/year)

OrganVolume_S; OrganVolume_L

Price of raw organic milk

(€ cents/kg)

Price_S; Price_L

Distribution channels

Distrib_LEH; Distrib_NK

Environmental management system

EMS_yes; EMS_no

Organisation

Family; Cooperative

Organic farmers' associations

Assoc_new; Assoc_trad

Demeter licence

Demeter_yes; Demeter_no

Number of employees

Employ_S; Employ_M; Employ_L

BNN membership

BNN_yes; BNN_no

Organic share

Organic $<20 \%$; Organic $>20 \%$;

Organic_100\%

GMO free certification

GMO_free; GMO_possible

Reusable glass packaging

Resusable_yes; Reusable_no
Depicts financial potential (small/medium/large); includes turnover of non-organic products.

Organic raw material available (small/large); indirectly points to market shares.

Average price (small/large) paid to farmers; highly contested indicator of cooperative relations towards contracted farmers.

Main distribution; distinguishes organic health food stores (NaturKostfachhandel $=$ NK) and conventional food retailers (LebensmittelEinzelHandel = LEH).

Indicates whether environmental activities are systematically audited.

Structure of ownership and decision-making; distinguishes cooperatives and family businesses.

Type of collaborating associations; newer associations basically require $\mathrm{EC}$ regulation, traditional associations have tighter guidelines.

Demeter is perceived as 'strictest' and least commercialised organic association. A licence requires membership and conformity with comprehensive (anthroposophical) criteria.

Reflecting both 'human capital' of the company and its economic size (small/medium/large).

Bundesverband Naturkost Naturwaren membership is restricted to dairies with more than $50 \%$ of turnover generated by organic products or special permit. Indicates commitment to the organic sector.

Ratio of organic milk to total amount of milk processed; indicates importance of organic sector to the dairy.

Complementing the restrictions on genetic engineering for organic products, dairies can get certified for avoiding GMOs in all processes.

Once the epitome of ecological packaging; today, reusable glass is challenged by life cycle assessment. 


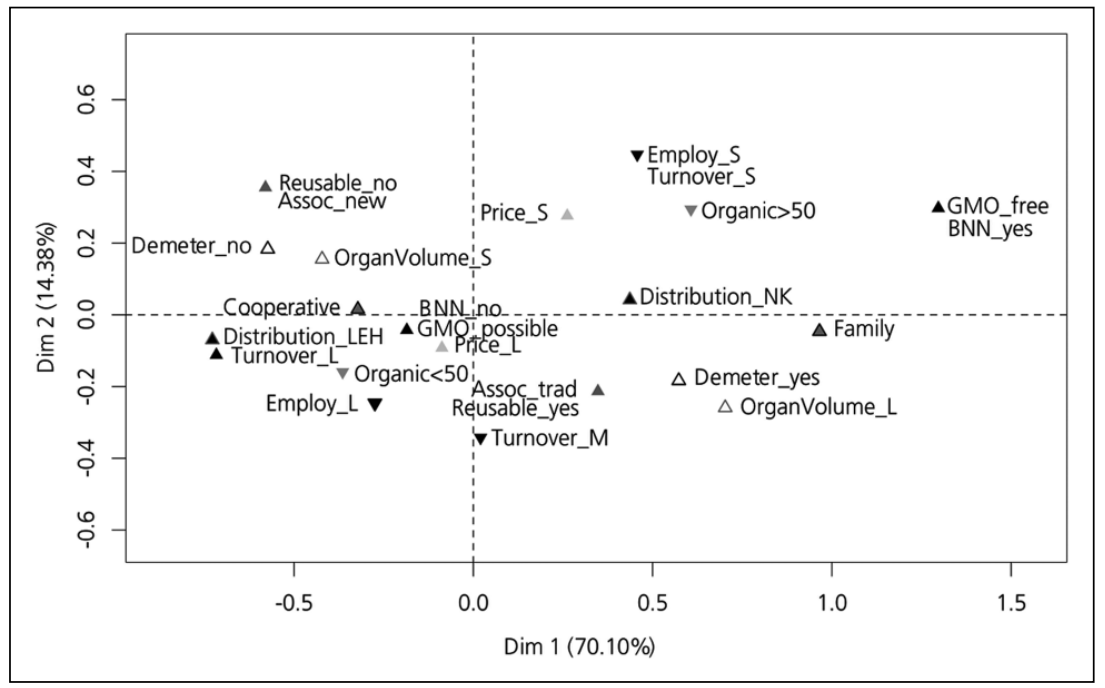

Figure 2. Bipolar structure of the market field in 200I, MCA based on potential power resources.

But how can we interpret this substantial dimension, what type of opposition does it represent? On the right, various attributes reflect what is denoted as ecosymbolic capital, i.e. capital generated by the appreciation for moral (or environmental) integrity. Characteristics such as Demeter certification, high share of organic milk, complete rejection of genetic engineering, distribution via organic food shops or consistent use of reusable packaging imply ecological prestige. At the same time, attributes indicating small economic size, such as family business, low turnover and small number of employees are also situated on the right. Eco-symbolic capital is thus associated with a lack of economic capital. In contrast, the left displays vast economic size and commercial orientation, e.g. a focus on conventional retailers or concessions to GMOs.

Consequently, the 2001 market field is structured by the opposition between economic size and ecological integrity. Referring to field theory, this dichotomy can be understood as two poles, the sacred and the profane. These are governed by opposing sets of values, i.e. an economic economy on the left and a noneconomic, symbolic economy on the right. What is valued in the economic economy (e.g. high turnover rates, commercial potential of non-reusable packaging) is viewed negatively in the symbolic economy. The 2001 structure is clearly ambivalent: two opposing sets of values are simultaneously valid.

It is important to consider the implications of ambivalence for market participants. They can either strive for economic growth or they build up their moral reputation. They cannot have both. Economic growth leads to a structural loss of moral integrity, while adherence to ecological orientation hinders commercial potential. The ambivalence of this bipolar structure does not leave much space for further development. Shifting in either direction means actors risk losing capital. The stagnation observed on the market following 2001 can at least be partly explained by this irreconcilable 
opposition. Caught in structural ambivalence, economic growth would jeopardise the moral integrity of the market and thus kill the goose that lays the golden egg.

Yet, history proves that the organic dairy market did recover and did grow enormously after 2005 (cf. Figure 1). So how was this structural ambivalence mitigated, how were economy and morality turned into complementary rather than opposing elements? The evolution of the market field and its underlying oppositions provide some answers.

Figure 3 displays the correspondence map based on data for 2011. We thus look at a moment when the market has seen massive growth for several years and is still on an upward trajectory. According to the ratios of explained variance and in contrast to the snapshot of 2001, the market field depicted here is truly two-dimensional. It is differentiated along two discernible axes. But what do they indicate? Has the dichotomy - economic size vs ecological integrity, economy vs morality - disappeared? Figure 4 summarises the interpretation of both dimensions. In brief, the dichotomy creating irreconcilable ambivalence in 2001 appears to have doubled and is now displayed on both axes. This allows for hybrid positions (particularly quadrant I) and potential synergies between economic and symbolic economies. Thus, ambivalence is still present but has unravelled into a more pluralistic structure.

The horizontal axis (dimension 1) is characterised by an apparent opposition. It comprises variables displaying economic size, such as number of employees, turnover or organisation type. At the same time, it is marked by variables expressing ecological orientation: quantity and share of organic milk, GMO-free certification, Demeter licences or BNN membership. The respective eco-symbolic capital is, however, primarily institutionalised capital. It is acquired through a focus on the organic market and involvement in environmental institutions. Some illustrative passive variables, displayed in light grey in Figure 3, support this interpretation: being a member of the Association of Organic Producers (AöL_yes), a signatory of a common declaration for organic milk (Signatory_ yes) or ranked by an ecological consumer magazine (ÖkoTest_yes) demonstrate environmental orientation. However, these variables point to institutions explicitly established to consecrate environmental integrity.

The horizontal axis thus has a dual function (see Figure 4): from right to left it reflects economic capital in terms of economic size - in the opposite direction it shows the degree of eco-symbolic capital in its institutionalised form.

The interpretation of the second dimension is less apparent, but still discernible if we consider the historic origins of the market. The vertical axis shows two very different historical perspectives of legitimate organic practices. The upper end reflects a 'modern' understanding of organic production processes, open to commercialisation and in line with the requirements of mass market distribution. This is expressed by the integration of less traditional farming associations, a complete rejection of inconvenient reusable packaging, distribution via conventional retailers - or even certified environmental management systems which make environmental protection a subject for rationalised auditing. The lower end of the axis, however, displays a more traditional interpretation, which shaped the market during its initial stage. Here, commercialisation is opposed and instead traditional practices are promoted.

A prime example supporting this interpretation is the homogenisation of fresh milk. Formerly, this practice was rejected outright due to ideological and health concerns. Only with time and accompanied by discursive controversies (Suckert, 2015) did 


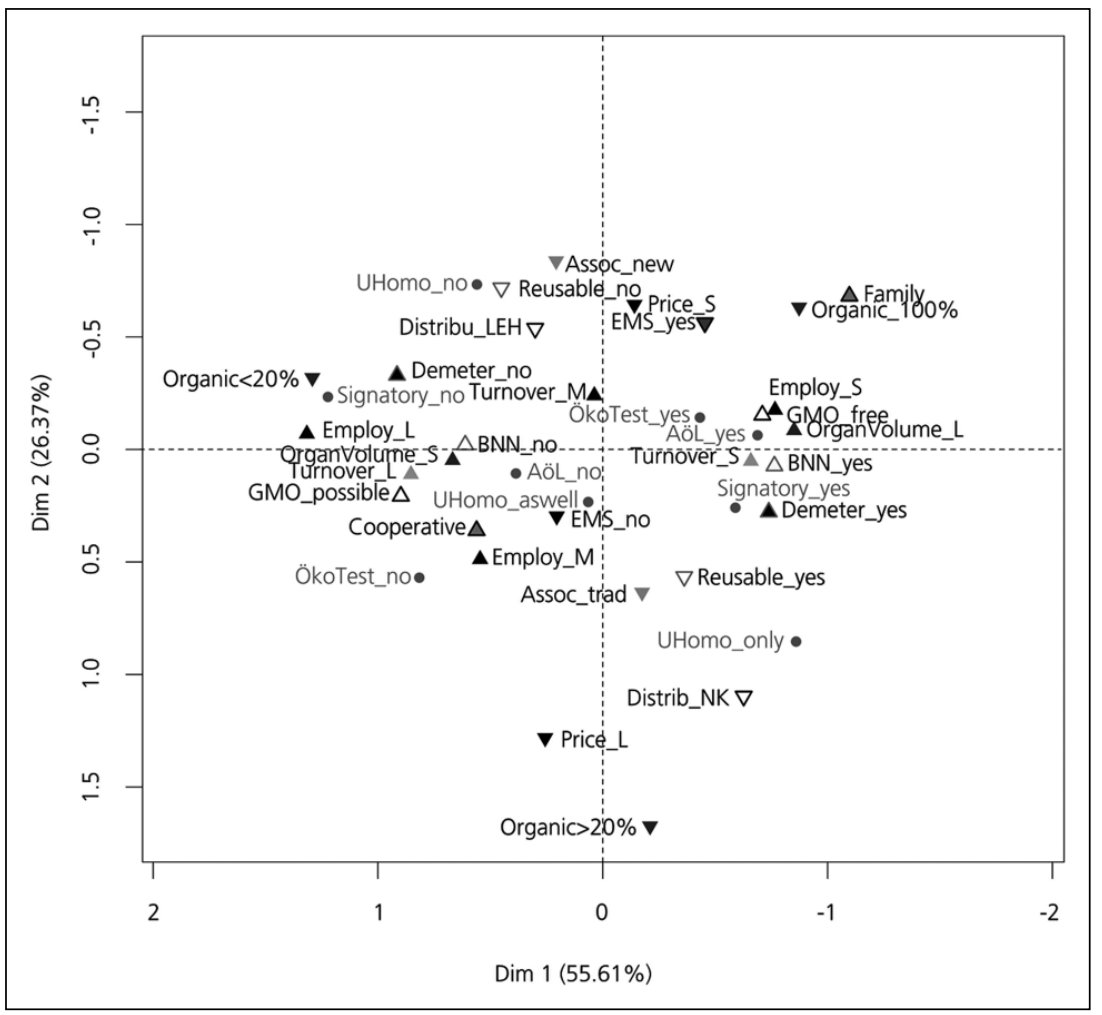

Figure 3. Structure of the market field in 20II, MCA based on potential power resources.

homogenisation become a legitimate step in organic processing. Homogenisation makes it easier to standardise and manage raw milk. This renders it more convenient for consumers as the irritating shaking of creamed milk is no longer necessary. Consequently, homogenising milk facilitates mass market distribution. In Figure 3, the degree of homogenisation is included as a passive, illustrative variable. I distinguish between dairies offering only unhomogenised fresh milk (UHomo_only), unhomogenised and other fresh milk (UHomo_aswell) or no unhomogenised fresh milk at all (UHomo_no). These three attributes are largely explained by the vertical axis and extend in the same direction: 'only unhomogenised milk', the ecologically sacred practice, is at the bottom, separated from the mass market. In contrast, 'no unhomogenised fresh milk' is found at the top where a more commercial orientation is situated.

Altogether, dimension 2 represents an opposition of organic philosophies. A traditional view of the organic dairy industry is juxtaposed with a more modern, commercial interpretation. ${ }^{8}$ Both positions are associated with different power resources. A perception of organic practices geared towards the mass market fosters commercial potential and additional economic capital. In contrast, resistance to commercial practices generates appreciation and eco-symbolic capital. Yet, this eco-symbolic capital differs from the capital indicated by the first dimension: it is not institutionalised but derived from 


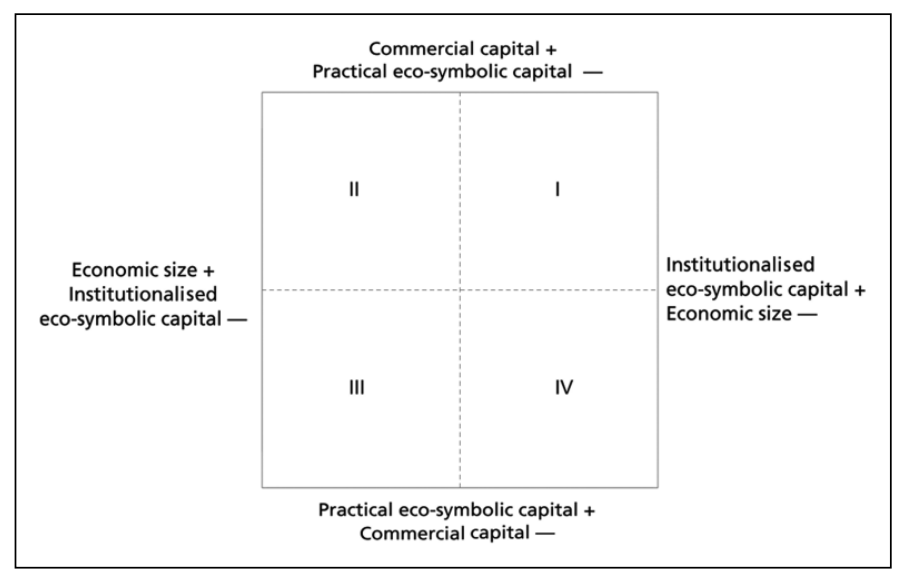

Figure 4. Structure and underlying oppositions of the market field in $201 \mathrm{I}$.

specific business practices. Unlike institutional eco-symbolic capital, it cannot be preserved through memberships or licences. Instead it must be repeatedly acquired through behaviour judged as morally desirable. It is therefore referred to as practical eco-symbolic capital.

In conclusion, the transformation from a bipolar to a two-dimensional field structure coincides with the duplication of the opposition between economy and ecological morality. This opposition is now represented by two distinguishable dimensions. The horizontal axis marks the contrast between economic size and institutionalised eco-symbolic capital, while the vertical axis spans the tension between commercial capital and practical eco-symbolic capital (see Figure 4). Ambivalence, understood as the opposition of two mutually exclusive sets of values, is thus unravelled into a multidimensional, more pluralistic structure.

\section{Unravelling ambivalence - enabling growth?}

The genuine novelty at the heart of this structural transformation is a reinterpretation of what is ecologically valuable in the market field. Over time, two independent modes of accumulating eco-symbolic capital were generated. The first is based on traditional practices assumed to be ecological; the second draws on consecrating institutions: labels, associations, licences and rankings.

The creation of the latter mode obviously needs to be considered in light of broader social developments such as quantification, professionalisation or the rise of intermediaries and rating agencies. According to the field-theoretical model of change, these are external influences. However, they were translated and adapted to the internal field struggles between the economic and eco-symbolic economy and thus altered the internal capital structure. While sustainable business studies have discussed consecrating institutions like labels as 'signalling devices', communicating ecological value to consumers (Boström and Klintman, 2008), the findings of this study reveal how their emergence 
substantially altered the meaning of ecological value, i.e. what is valuable within the market field.

This transformation of the capital structure has been contested within the field (Suckert, 2015: 354), but, more importantly, it had major implications for participants' strategies and overall market growth. Within the transformed and therefore more pluralistic structure, actors can combine both economic and symbolic resources. Commercial capital in particular becomes compatible with the novel, institutionalised type of ecosymbolic capital.

This combination is represented by quadrant I of Figure 4. Tellingly, both market leaders responsible for major growth since 2005, Andechser and Söbbeke, are located here. These 'dual beings', as Bourdieu would call them, combine organic tradition and participation in ecological institutions (dimension 1) with commercial potential and access to the organic mass market (dimension 2). Their hybrid, i.e. economic and symbolic, capital stocks provide synergies. Both dairies invoke their licences and memberships as a unique selling proposition. Their environmental integrity enables them to better exploit their commercial potential. At the same time, strong revenues generated by organic products allow for an exclusive focus on this market. Operating as 100\% organic dairies, they are considered 'pure' and qualify as members of major organic associations. Thus, these dairies use their commercial success to build up their ecological reputation and vice versa.

However, what appears as these market leaders' viable business strategy is profoundly embedded in a particular market structure. The hybrid capital stocks they possess only became accessible when two distinctive types of eco-symbolic capital and thus a more pluralistic structure emerged - and ambivalence unravelled. Embedded in a bipolar structure similar to the one described for 2001, the same strategy would have led to the destruction of (symbolic) capital. This structural transformation, which builds on labels, associations, licences and rankings, does not exclusively cause or determine the subsequent growth and the transition from niche to mass market - but it certainly facilitates it.

\section{Conclusion}

The invisible hand of moralised markets is supposed to reconcile the irreconcilable: selfishly maximising profit while altruistically doing good. I have argued that considering ambivalence, i.e. the simultaneous validity of opposing sets of values, is crucial to understanding the structure and dynamics of moralised markets. The correspondence analysis of the German organic dairy market has demonstrated how a market field can be governed by two opposing principles, economy and ecology. However, this bipolar structure transformed into a multidimensional pattern. Implied ambivalence unravelled as economic orientation and moral integrity became more compatible, because divergent and independent modes of moral appreciation emerged. Market growth was thus facilitated by structural changes.

Despite these insights, this study is subject to limitations. First, it draws on one comprehensive, though singular case. Generalisations should be regarded with caution while comparison with other moralised markets is desirable. Moreover, this analysis remains at the structural level. It makes the market field its primary unit of analysis. Some external 
influences have been mentioned, but I have not paid particular attention to the market actors or their respective strategies. I have, at least in this article, omitted the micro processes of agency, translating these external influences into internal struggles and thus underlying the structural transformation: the initiatives and coalitions fostering institutions of ecological consecration (e.g. labels, certificates, awards, associations); the financial and discursive effort to reframe and 'de-ideologise' organic practices. Though I did not focus on micro-level agency, the suggested field-theoretical approach is intentionally designed to overcome both the micro-macro and the structure-agency divide. The concept of habitus, which, due to my analytical focus, was almost ignored in this study, is crucial in this respect. Research on 'hybrid actors', mentioned in the introduction of this article, as well as work based on IL or EC approaches could therefore not only complement this study but eradicate some of its analytical hyperopia. Nevertheless, the findings emphasise that the behaviour of such actors cannot be reduced to rational, individual or situational action. The ability to cope with ambivalence is not merely the result of an intentional strategy, but it is dependent on a specific historic field structure and respective dispositions of actors. The market field in which 'hybrid actors' operate, its underlying oppositions and their evolution should thus be considered more comprehensively.

In addition, this study may advance the agenda of economic sociology. Ambivalence is most pronounced in moralised markets because morality is made explicit here. Nevertheless, as new economic sociology considers all markets to be embedded, all markets - from the derivative market to the market for child pornography - appear ambivalent. Markets are always (if to varying degrees) governed by distinguishable and often opposing logics: economic and noneconomic ones. Economic sociology should therefore take ambivalence into account. But it should not stop at identifying other, noneconomic factors. Instead, sociologists investigating ambivalence in markets should focus on the conflicts and synergies originating from divergent sets of values. Both IL and EC already offer suitable concepts and are particularly useful for the study of divergent values and their dynamics. However, complementing these approaches with a field-analytical perspective allows focusing on opposing values and the structural effects they have on power relations and actors' dispositions. In this respect, the fieldanalytical perspective suggested in this article can only be an initial step for further theoretical development.

\section{Acknowledgements}

I am grateful to my colleagues at the Max Planck Institute for the Study of Societies for their constructive feedback and help. Timur Ergen and Thomas Angeletti commented on an earlier version of this article, which was also presented at the Score International Conference on Organizing Markets. The study underpinning this article was conducted at the University of Bamberg and benefited from Richard Münch's insightful comments and suggestions. I would also like to thank three anonymous reviewers and the editors in charge for their constructive and encouraging critique.

\section{Funding}

This research received no specific grant from any funding agency in the public, commercial, or not-for-profit sectors. 


\section{Notes}

1. Assuming two opposing sets of values - moral and economy - implicitly draws on classical German idealism. In contrast, Fourcade and Healy (2007) use the notion of 'moralised markets' to depict the blurring distinction between moral and economy as nowadays markets become moral institutions in their own right.

2. In semi-structured interviews, CEOs and marketing directors of eight dairies were asked for their competitors (Suckert, 2015: 332).

3. A discourse analysis scrutinised 300 articles from two leading food industry journals (Schrot\&Korn, LebensmittelZeitung) addressing organic milk from 1985 to 2011.

4. Sources: Dairies' annual reports, Federal Gazette (Bundesanzeiger); dairies' websites and former websites via Wayback Machine; (historic) leaflets and advertisements; interviews with dairy representatives; articles from LebensmittelZeitung, LebensmittelPraxis, local newspapers and trade register notices via the WISO database; historic articles from Milch-Marketing, Deutsche Milchwirtschaft, Lebendige Erde, ÖkoTest and Ökologie\&Landbau accessed via library of TU München for the years 1985-2000; websites of and telephone enquiries to Greenpeace, organic farmers' associations and BNN; yearbooks Ökomarkt Jahrbücher 19952009 (ZMP).

5. Bourdieu used MCA to visualise underlying field structures, i.e. relevant types of capital and their opposition (Lebaron, 2009). An extension of simple correspondence analysis (e.g. Chua, 2013), MCA emanates from singular value decomposition: complex interrelations between items are expressed by fewer latent dimensions.

6. The correspondence maps originate from MCA of 13 main indicators, using $\mathrm{R}$ and specifically the package FactoMineR (Lê et al., 2008). Some additional variables were used as passive elements to facilitate and strengthen interpretation.

7. MCA based on Burt matrix.

8. Based on EC, Boisard (1991) famously observed a similar opposition between 'traditional' and 'industrial' approaches to producing French camembert. For an overview of EC studies addressing the wider field of agro food, see also Ponte (2016).

\section{References}

Beckert J (2009) The social order of markets. Theory and Society 38(3): 245-269.

Beckert J (2010) How do fields change? The interrelations of institutions, networks, and cognition in the dynamics of markets. Organization Studies 31(5): 605-627.

Bleuler E (1914) Die Ambivalenz. In: Festgabe zur Einweihung der Neubauten der Universität Zürich (Festgabe der medizinischen Fakultät), Zürich, pp. 95-106.

Bode I (2015) A 'world culture' of institutional ambiguity? Comparing the reorganization of hospital care in Germany and Mexico. Current Sociology 63(3): 411-431.

Boisard P (1991) The future of a tradition: Two ways of making camembert, the foremost cheese of France. Food and Foodways 4(3-4): 173-207.

Boltanski L and Thévenot L (2006) On Justification: Economies of Worth. Princeton, NJ: Princeton University Press.

Boström M and Klintman M (2008) Eco-Standards, Product Labelling and Green Consumerism. Basingstoke: Palgrave Macmillan.

Bourdieu P (1972) Esquisse d'une théorie de la pratique: Précédé de trois études d'ethnologie kabyle. Geneva: Éditions Droz.

Bourdieu P (1994) Raisons pratiques. Sur la théorie de l'action. Paris: Seuil.

Bourdieu P (1996a) La double vérité du travail. Actes de la Recherche en Sciences Sociales 114(1): 89-90. 
Bourdieu P (1996b) The Rules of Art: Genesis and Structure of the Literary Field. Stanford, CA: Stanford University Press.

Bourdieu P (1997) Le champ économique. Actes de la Recherche en Sciences Sociales 119(1): 48-66.

Bourdieu P (1998) Practical Reason: On the Theory of Action. Stanford, CA: Stanford University Press.

Bourdieu P (2002) The forms of capital. In: Biggart NW (ed.) Readings in Economic Sociology. Malden, MA: Blackwell, pp. 280-291.

Bourdieu P and Christin R (1990) La construction du marché. Actes de la Recherche en Sciences Sociales 81(1): 65-85.

Child C (2012) Chasing the double-bottom line: Fair trade and the elusive win-win. In: Gidron B and Hasenfeld Y (eds) Social Enterprises. Basingstoke: Palgrave Macmillan, pp. 185-197.

Chua V (2013) Contextualizing 'networked individualism': The interplay of social categories, role relationships and tasks. Current Sociology 61(5-6): 602-625.

Clercq DD and Voronov M (2009) The role of domination in newcomers' legitimation as entrepreneurs. Organization 16(6): 799-827.

Diaz-Bone R (2014) Methodological positionings and perspectives: Comparing economics of convention with the institutional logics approach. Journal of Management Inquiry 23(3): 324-327.

Diaz-Bone R and Salais R (eds) (2012) The économie des conventions. Special issue of Historical Social Research 37(4).

Fligstein N (1990) The Transformation of Corporate Control. Cambridge, MA: Harvard University Press.

Fligstein N (2002) The Architecture of Markets: An Economic Sociology Of Twenty-First-Century Capitalist Societies. Princeton, NJ: Princeton University Press.

Fligstein N and McAdam D (2011) Toward a general theory of strategic action fields. Sociological Theory 29(1): 1-26.

Fligstein N and McAdam D (2012) A Theory of Fields. New York: Oxford University Press.

Fourcade M and Healy K (2007) Moral views of market society. Annual Review of Sociology 33: 285-311.

Friedland R and Alford RR (1991) Bringing society back in: Symbols, practices and institutional contradictions. In: Powell WW and DiMaggio P (eds) The New Institutionalism in Organizational Analysis. Chicago, IL: University of Chicago Press, pp. 232-263.

Friedman M (1970) The social responsibility of business is to increase its profits. The New York Times Magazine, 13 September, p. 32.

Gibbs D (2009) Sustainability entrepreneurs, ecopreneurs and the development of a sustainable economy. Greener Management International 55: 63-78.

Granovetter M (1992) Problems of explanation in economic sociology. In: Nitin N and Eccles RG (eds) Networks and Organizations: Structure, Form, and Action. Boston: Harvard University Press, pp. 25-56.

Greenacre MJ and Blasius J (eds) (2006) Multiple Correspondence Analysis and Related Methods. Boca Raton, FL: Chapman and Hall.

Hahn T, Pinkse J, Preuss L et al. (2016) Ambidexterity for corporate social performance. Organization Studies 37(2): 213-235.

Hockerts K and Wüstenhagen R (2010) Greening Goliaths versus emerging Davids: Theorizing about the role of incumbents and new entrants in sustainable entrepreneurship. Journal of Business Venturing 25(5): 481-492.

Jagd S (2007) Economics of convention and new economic sociology. Current Sociology 55(1): 75-91. 
Knoll L (2012) Über die Rechtfertigung wirtschaftlichen Handelns. Wiesbaden: Springer VS.

Lê S, Josse J and Husson F (2008) FactoMineR: An R package for multivariate analysis. Journal of Statistical Software 25(1): 1-18.

Lebaron F (2009) How Bourdieu 'quantified' Bourdieu: The geometric modelling of data. In: Robson K and Sanders C (eds) Quantifying Theory: Pierre Bourdieu. Dordrecht: Springer Netherlands, pp. 11-29.

Mair J, Mayer J and Lutz E (2015) Navigating institutional plurality: Organizational governance in hybrid organizations. Organization Studies 36(6): 713-739.

Merton RK (1976) Sociological Ambivalence and Other Essays. New York: Simon and Schuster.

Murray F (2010) The oncomouse that roared: Hybrid exchange strategies as a source of distinction at the boundary of overlapping institutions. American Journal of Sociology 116(2): 341-388.

Pache A-C and Santos F (2013) Inside the hybrid organization: Selective coupling as a response to competing institutional logics. Academy of Management Journal 56(4): 972-1001.

Phillips M (2013) On being green and being enterprising: Narrative and the ecopreneurial self. Organization 20(6): 794-817.

Ponte S (2016) Convention theory in the Anglophone agro-food literature: Past, present and future. Journal of Rural Studies 44: 12-23.

Powell WW and DiMaggio PJ (1983) The iron cage revisited: Institutional isomorphism and collective rationality in organizational fields. American Sociological Review 48(2): 147-160.

Reay T and Hinings CR (2009) Managing the rivalry of competing institutional logics. Organization Studies 30(6): 629-652.

Rosenkranz T (2016) Becoming entrepreneurial: Crisis, ethics and marketization in the field of travel journalism. Poetics 54: 54-65.

Schaltegger S (2010) A framework and typology of ecopreneurship: Leading bioneers and environmental managers to ecopreneurship. In: Schaper M (ed.) Making Ecopreneurs: Developing Sustainable Entrepreneurship. Farnham: Gower, pp. 75-95.

Smelser NJ (1998) The rational and the ambivalent in the social sciences: 1997 Presidential Address. American Sociological Review 63(1): 1-16.

Sparsam J (2015) Wirtschaft in der New Economic Sociology - Eine Systematisierung und Kritik. Wiesbaden: Springer VS.

Stehr N, Henning C and Weiler B (2006) The Moralization of the Markets. New Brunswick, NJ: Transaction Publishers.

Suckert L (2014) Organisierter Kompromiss: Wie Ecopreneur-Unternehmen das Dilemma der Nachhaltigkeit lösen. In: Knoll L (ed.) Organisation und Konvention: Die Soziologie der Konventionen in der Organisationsforschung, Wiesbaden: Springer VS, pp. 193-224.

Suckert L (2015) Die Dynamik ökologischer Märkte: Eine feldanalytische Betrachtung des Marktes für Bio-Molkereiprodukte. Konstanz: UVK.

Swedberg R (2009) Principles of Economic Sociology. Princeton, NJ: Princeton University Press. Swedberg R (2011) The economic sociologies of Pierre Bourdieu. Cultural Sociology 5(1): 67-82.

Thévenot L (2001) Organized complexity conventions of coordination and the composition of economic arrangements. European Journal of Social Theory 4(4): 405-425.

Thornton PH and Ocasio W (1999) Institutional logics and the historical contingency of power in organizations: Executive succession in the higher education publishing industry, 1958-1990 1. American Journal of Sociology 105(3): 801-843.

Varriale S (2015) Cultural production and the morality of markets: Popular music critics and the conversion of economic power into symbolic capital. Poetics 51: 1-16.

Villiger A, Wüstenhagen R and Meyer A (2000) Jenseits der Öko-Nische. Basel: Birkhäuser.

Witman Y, Smid GAC, Meurs PL et al. (2011) Doctor in the lead: Balancing between two worlds. Organization 18(4): 477-495. 
Zelizer V (1983) Morals and Markets: The Development of Life Insurance in the United States. New Brunswick, NJ: Transaction Publishers.

ZMP (2002) Ökomarkt Jahrbuch 2002. Bonn: ZMP.

\section{Author biography}

Lisa Suckert is a senior researcher at the Max Planck Institute for the Study of Societies in Cologne, where she principally investigates the dynamics of future expectations in moments of crisis. She received her PhD from the University of Bamberg, Chair for Sociological Theory. Her main research interests are economic sociology, organisational sociology and research on capitalism. Lisa Suckert's work is theoretically inspired by field theory and économie des conventions and empirically based on a mixed methods approach including correspondence analysis and quantitative and qualitative discourse analysis, for instance.

\section{Résumé}

Les marchés moralisés sont souvent décrits comme des marchés de consommation éthique, censés atténuer une contradiction apparente dans les sociétés capitalistes, à savoir le conflit entre moralité et économie. Mais dans quelles conditions ces marchés se développent-ils, et quand stagnent-ils ? En s'éloignant de l'approche dominante qui s'intéresse avant tout aux contraintes externes, cet article met l'accent sur l'ambivalence intrinsèque des marchés moralisés. La tension entre des exigences morales et économiques devient un obstacle à la croissance du marché. L'objet de cet article est de tenter de percer cette ambivalence, et ce, à deux niveaux. Premièrement, le cadre théorique des champs nous sert à déchiffrer la notion d'ambivalence. Inspiré par Pierre Bourdieu, l'article propose d'introduire dans la sociologie économique l'ambivalence comme catégorie analytique. Deuxièmement, une étude historique fondée sur l'analyse des correspondances s'intéresse au développement du marché du lait bio en Allemagne. La distinction entre croissance et stagnation se situe dans le degré d'ambivalence dans ce marché. Ce n'est que si l'opposition est mitigée et que l'ambivalence se dissipe dans une structure de champ plus pluraliste que le passage d'un marché de niche à un marché de masse devient viable.

\section{Mots-clés}

Ambivalence, Bourdieu, conventions, logique institutionnelle multiple, marchés, moralité, sociologie économique, théorie des champs, viabilité

\section{Resumen}

Los mercados moralizados se conocen a menudo como mercados de consumo ético. Se supone que alivian una fuente importante de inquietud en las sociedades capitalistas: el conflicto entre la ética y la economía. Pero, ¿en qué condiciones crecen estos mercados y cuándo se estancan? Desviándose del enfoque dominante centrado en las restricciones externas, este artículo enfatiza la ambivalencia intrínseca de los mercados moralizados. Estar atrapado entre exigencias morales y económicas se convierte en un obstáculo para el crecimiento del mercado. El artículo trata de 'descifrar la ambivalencia' en dos niveles: Primero, se utiliza el marco teórico de campos para desentrañar el concepto de ambivalencia. Inspirado por Pierre Bourdieu, el artículo propone introducir la ambivalencia como una categoría analítica en la sociología económica. En segundo lugar, 
un estudio histórico basado en el análisis de correspondencias describe el desarrollo del mercado alemán de la leche biológica. Lo que distingue al crecimiento del estancamiento es el grado de ambivalencia dentro de este mercado. Sólo si la oposición se mitiga y la ambivalencia se desentraña en una estructura de campo más pluralista, la transición desde el nicho de mercado al mercado de masas se hace viable.

\section{Palabras clave}

Ambivalencia, Bourdieu, convenciones, mercados, moralidad, múltiples lógicas institucionales, sociología económica, sostenibilidad, teoría de campo 